\title{
The Study of East Wind. West Wind from the Perspective of the Third Space Theory
}

\author{
Jie Kang \\ School of Letters \& Arts, Shaanxi Normal University, Xi'an Shaanxi, 710119, China
}

Keywords: East Wind. West Wind, The Third Space, Integration, Cultural Identity.

\begin{abstract}
As a marginalized person living between two cultures, Pearl S. Buck makes her efforts to achieve the integration of the Eastern and Western cultures throughout her life. East Wind- West Wind is Pearl S. Buck's first novel and reflects her ideal. Living in the cracks of two cultures, Pearl S. Buck gradually adapts herself to the alienation of the two cultures and begins to seek for a way to achieve cultural integration, and try to establish the unique cultural identity of her own.
\end{abstract}

\section{The third space theory and hybridity}

The Third Space Theory is posed by Homi Bhabha, a post-colonialist theorist, in his representative work The Location of Culture. What does the "third" mean? It refers to a position that transcends the traditional binary opposition and takes on a dubious appearance which cannot be definitely categorized as this or that. And generally speaking, the Third Space refers to a knowledge space which is in the outside of binary opposition. The product of this space is just called the heterozygous cultures which share the features of the two different cultures.

When explaining the diversity of cultures, Homi Bhabha once said:

It is significant that the productive capacities of this Third Space have a colonial or postcolonial provenance. For a willingness to descend into that alien territory-where I have led you may reveal that the theoretical recognition of the split-space of enunciation may open the way to conceptualizing an international culture, based not on the exoticism of multiculturalism or the diversity of cultures, but on the inscription and articulation of culture's hybridity (Bhabha 56).

From this we may find that Bhabha's third space theory, on the one hand, is opposed to essentialism. On the other, it is not completely spilt, full of differences but still have relationships with each other. In short, the Third Space is a mixed space and a space of cultural significance, which belongs to neither the East nor the West. Homi Bhabha's Third Space theory makes great contributions to the collapse of binary opposition between dominant culture and vulnerable culture, and provides a way to promote exchanges between different cultures.

Pearl S. Buck, as a marginalized person living in a confusing and embarrassing situation, drifts between traditional Chinese culture and American mainstream culture. In My Several Worlds: A Personal Record, Pearl S. Buck wrote that she grew up in a double world, the small white clean Presbyterian American world of her parents and the big loving merry not-too-clean Chinese world, which was no communication between them. (10)

So she does not know where she really belongs to and how to define her cultural identity. she clearly realizes that it is essential to get rid of the identity debate on bridging different kinds of cultures. She has to create her own cultural identity in the contradictions of conflicts. She makes her efforts to seek for a third space and reflects her wish in her literary creation. 


\section{Pearls buck’s cultural idea in eastwind-westwind}

As Pearl S. Buck's first novel, East Wind - West Wind reflects her idea---seek for a way to achieve cultural integration, and try to establish the unique cultural identity of her own.

The issues at stake in East Wind - West Wind are "the contest of between tradition and modernity and the risks and possibilities of human connection across racial and cultural lines". (Conn 83) In East Wind . West Wind, one of the heroines of the story tells stories of her own and her brother to her foreign girlfriend who has been in China for a long time and knows quite a lot about Chinese customs and values. Through the vivid narration of these stories, we can clearly see the differences between Chinese and American cultures. Pearl S. Buck enables people to see her different attitudes toward these characters in dealing with cultural differences. And to a great extent, she reveals the characteristics in the family and marriage aspects from perspectives of both Chinese culture and American one. At the same time, she also shows her own judgments on values and choices.

The heroine of the story, Kwei-lan is deeply affected by the traditional feudal thoughts at first, and seems to be incompatible with her husband who comes back from the West, but at last she is greatly influenced by the radical western democratic ideas. Kwei-lan had been instilled strong feudal ideas by her mother at a very early age. In her opinion, women are inherently inferior to men and boom to have the obligations to give birth to and raise children, to please her husband and her in-laws, Like the majority of traditional Chinese women at that time. They are used to depending on their husbands and thus lose their independent will and individuality. However, under the ideas of equality and democracy, Kwei-lan's husband holds the view that the relationship between husband and wife should be mutually equal rather than affiliation. He even wants to transform and improve their marriage through their own efforts.

In the novel, Kwei-lan feels at a loss when her husband tells her at the wedding night that he would treat her as friend rather than slave or property. The husband has so advanced and civilized ideas that Kwei-lan even doesn't know what she should do. From Kwei-lan's description we know that her husband is a doctor who has studied abroad for twelve years. In his opinion, he hopes to use the democratic ideas learned in the United States to transform his wife who has been deeply influenced by feudal thoughts from an early age. Just from here, the conflicts between the couple's concepts emerge. And this conflict is essentially a reflection of cultural conflicts between China and America.

There is a vivid example showing the conflicts between traditional thoughts and modem ideas in the novel: That is Kwei-lan's bound-feet. Kwei-lan used to be very proud of her feet under the inculcation of her mother's feudal ideas. Unexpectedly, her husband thinks that the feet are not beautiful and insists that she should release the bindings. Kwei-lan's husband says to her: "I have wished ever since our marriage to ask you if you will not unbind your feet. It is unhealthful for your whole body. See, your bones look like this."(East Wind 55) Apparently at the beginning, she could not understand her husband's decision. "I was stricken at his words. Not beautiful? I had always been proud of my tiny feet! All during my childhood my mother herself had superintended the soaking in hot water and the wrapping of the bandages-tight and more tight each day. When I wept in anguish she bade me to remember that someday my husband would praise the beauty of my feet."(East Wind 56)

From the husband's point of view, the bound feet are just like the shackles of feudal ideology imposed on people. One can only unbind body to better emancipate the mind. From these we can see that the conflicts between the couple's concepts reflect the cultural differences between the East and the West.

If we may say the conflicts between Kwei-lan and her husband aroused by the differences between Eastern and Western cultures are indirect, the conflicts between Kwei-lan's parents and her brother and her sister-in-law are direct. In the second part of the novel, Kwei-lan's brother wants to marry the American girl, Mary. He writes to his parents to request permission to marry Mary as his wife and cancel the childhood marriage laid down by the parents. However, the parents not only severely reject his request, but also order him to return home to fulfill his obligations immediately. This manifests 
the conflicts and contradictions between the traditional feudal thoughts and western civilizations. Finally, Kwei-Ian's brother would rather sever relationship with the family and make his name removed from the family tree than leave his beloved wife. Soon Kwei-lan's brother has his own son, Kwei-lan describes her worry brought about by the birth of the child: the child's mother comes to a completely unfamiliar world from her home while the child's father cut off all contacts with his family. Because of the birth of the child, we have to re-consider how to build a cultural identity in the foreign land, and how to treat the local Chinese culture and foreign ones in a more reasonable way.

There must be conflicts and collisions between different cultural backgrounds, but it does not mean that the native and the exotic cultures would always be in a binary opposition. With the continuous guidance and help of her husband, Kwei-lan begins to adopt enlightened ideas gradually. She changes her resistant attitude toward various things of the West and then lives in a more harmonious way with her husband. She accepts her husband's many suggestions and gets rid of many feudal habits. She releases the feet bindings and accepts her husband's westernized life style step by step. Her husband even begins to teach her some basic scientific knowledge and radical modern ideas. With the husband's help, Kwei-lan realizes that foreign countries are not always barbarian ones and she even chooses something helpful for her use in a selective way to make combination with Chinese philosophy. Through the author's description, we can perceive the gradual development in her thinking modes and value system. She learns to take what she needs from the West and to adapt it to her Chinese context. Finally, Kwei-lan departs herself from Chinese ancient thinking patterns and reconstructs or embraces a new way of thinking. And all of these reflect Pearl S. Buck's cultural idea: through mutual respect, mutual communication and getting along well with each other in a harmonious way, different cultures could ultimately achieve complementarity and integration. Just like the Kwei-lan's brother's son who is neither purely an oriental nor a Westerner, but this child brings a combination of the new and the old, as well as the East and the West.

Pearl S. Buck is aware of the fact that she is deeply rooted in the two different cultures and abandoning any one kind of cultural values cannot be accepted. She makes full use of her unique "in-between" superiority and converts it into the power of connecting the two worlds of East and West.

\section{conclusion}

In East Wind - West Wind, the heroes and heroines Pearl portrays are the products of cultural integration. They do not belong to one single culture but own hybrid cultural identities through the process of integration. In fact, the confrontation and conflict between cultures are not so tough for us to deal with, and what matters is our attitudes toward it. We have to adopt a tolerant attitude toward the conflicts between Chinese and American cultures in order to reach the state of harmony. Of course, it does not mean we can realize the dream of the disappearance of the cultural contradictions, but the emergence of a new culture, in other words, the establishment of a "Third Space". According to Homi Bhabha's theories, if there is contact between two cultures, the otherness culture would agree with the mainstream culture without losing its own independence. There must be a process of hybridity in the Third Space.

In fact, East Wind - West Wind implies the unique life experiences of Pearl S. Buck. She thinks that she could adapt to the life living between the cracks of different cultures like the characters in the story and make continuous efforts to achieve the integration and harmony of different cultures. She is seeking for a way to reinterpret the traditional Chinese culture and American culture until the two cultures come into a new state of harmony.

Pearl S. Buck makes her efforts to get rid of her dilemma of living in the cracks of two different cultures throughout her life. The successful construction of "the Third Space" means the realization of harmonious coexistence of the two cultures. In this space. Pearl S. Buck finds her own cultural belongings and the solutions to dealing with cultural conflicts. Wherever she goes, she would not feel confused any longer. 


\section{References}

[1] Bhabha, Homi K. The Location of Culture (2nd revised edition). London \& New York: Routledge, 2004. Print.

[2] Buck, Pearl S. East Wind· West Wind. New York: John Day, 1932.Print.

[3] My Several Worlds. New York: John Day, 1954. Print.

[4] Conn, Peter. Pearl Buck: A Cultural Biography. New York: Cambridge University Press, 1996.Print.

[5] Hoogvelt, Ankie. Globalization and the Postcolonial World: The New Political Economy of Development, Baltimore: The John Hopkins University Press, 1997. Print.

[6] Sheng, Anfeng. The Postcolonial Theory Study On Homi Bhabha. Beijing: Beijing University Press, 2011. Print.

[7] Wang, Jianxiang and Jiequn, Wang. "Anxiety, Seeking and Rebuilding: Pearl S. Buck's Cultural Identity". Journal of Jiangsu University (Social Science), 2(2005):39-44. Print.

[8] Wang, Ning. Globalization: Literature Study and Culture Study. Guilin: Guangxi Normal University Press, 2003. Print.

[9] "Culture Identity in Literature Study". Foreign Literature 4(1999): 48-51. Print.

[10]"Narration, Cultural Position and Identity: The Postcolonial Theory On Homi Bhabha". Foreign Literature 6(2002): 48-55. Print. 